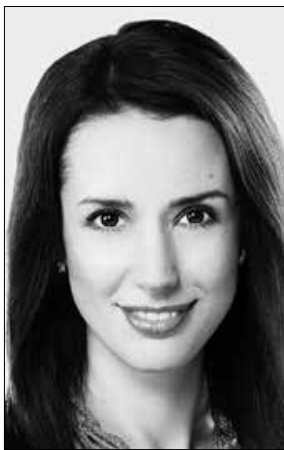

https://doi.org/10.24101/logos.2019.63

Gauta 20190409

\title{
VAIDA BUIVYDIENÉ
}

Vilniaus Gedimino technikos universitetas, Lietuva

Vilnius Gediminas technical University, Lithuania

\section{VĖLYVO BENDRINĖS KALBOS SU(SI)KŪRIMO SOCIOKULTÜRINĖS APLINKYBĖS: LIETUVIŲ BENDRINĖS KALBOS ATVEJIS} The Sociocultural Background of Late Formation of Standard
Language: Case Study of Lithuanian Standard Language

SUMMARY

Recent discussions concerning the policy of language, the normalisation of Lithuanian standard language, the issues of the necessity of language standards and norms, and the abolishment of the long-prevailing list of Gross language mistakes encourage closer studies at the sources of the Lithuanian language. This article deals with the reasons for the late formation of Lithuanian standard language and the sociocultural situation of the European historical context. Based on the theory of standard language development by Einar Haugen, the article gives an overview of the formative periods of Lithuanian standard language as well as the influence sociocultural factors. The article concludes that political and social aspects have had a tremendous impact on the development of Lithuanian standard language. The periods of development of Lithuanian standard language rapidly changed each other. Some of them even went side by side, while the others continue to be in process. A rather liberal attitude towards using language standards has been traced recently. An increase in the number of variants to be used have appeared in public. This increase could be the beginning of a period of destabilisation of standards.

\section{SANTRAUKA}

Pastarojo meto diskusijos viešojoje erdvèje kalbos politikos ir lietuvių bendrinės kalbos norminimo bei kalbos normiškumo ir standartiškumo poreikio klausimais, ilgus metus galiojusio Didžiųjų kalbos klaidų sąrašo paskelbimas negaliojančiu skatina atidžiau panagrinėti lietuvių bendrinės kalbos su(si)kūrimo ištakas. Šiame straipsnyje analizuojamos vèlyvo lietuvių bendrinės kalbos susiformavimo priežastys ir sociokultūrinės aplinkybės atsižvelgiant i Europos istorinį kontekstą. Straipsnyje, remiantis Einaro Haugeno bendrinių 
kalbų raidos teorija, apžvelgiami lietuvių bendrinès kalbos formavimosi tarpsniai ir juos nulèmę veiksniai. Daroma išvada, kad lietuvių bendrinès kalbos raidos istorijoje galima įžvelgti labai ryškią politinių ir socialinių reiškinių įtaką. Lietuvių bendrinės kalbos raidos tarpsniai greitai keitė vienas kitą, kai kurie net vyko greta bei tęsiasi iki šių dienų. Pastarųjų metų kalbos normų laisvẻjimas ir variantų gausẻjimas viešojoje erdveje rodo galimai prasidejjusį ir normų destabilizacijos laikotarpị.

\section{IVADAS}

Keičiasi ne tik kalbos, bet ir kalbos teorijos bei ideologijos, nes patiria socialinių bei kultūrinių reiškinių ir politikos itaką. Todèl net kai kodifikuotos kalbos normos būna jau visai neblogai įsitvirtinusios vartosenoje, dèl kitų veiksnių poveikio (labiausiai - dèl bendrinès kalbos sąveikos su kitomis kalbos atmainomis), atsiranda didesnis arba mažesnis realiosios bendrinès kalbos vartosenos ir kodifikuotų normu atotrūkis, nes gyvų kalbų pokyčiai yra natūralūs ir neišvengiami (Miliūnaitè 2006; 2018).

Bendrinių kalbų kūrimo teorija ir praktika susijusi su sąmoningais kalbos norminimo sprendimais (plg. su kitomis kalbos atmainomis, kuriu specialiai norminti ir kodifikuoti nereikia), kai tam tikru valstybès kūrimosi ar jau egzistavimo metu, susiformavus tinkamoms aplinkybėms, iškyla poreikis pasirinkti vieną kalbos atmainą arba suteikti ypatingą statusą vienai ar kelioms valstybejje nuo seno vartojamoms kalboms (Buivydienè 2013; Smetonienè 2014). Sociolingistikos atstovai Jamesas ir Lesley Milroy'jai mano, kad norminimo klausimus tiksliau yra vadinti ideo- logija, nes bendrinè kalba "yra labiau idèja, negu realybe்" (Milroy J., Milroy L. 1999: 19). Irena Smetonienè teigia, kad „kalba yra valstybės tam tikras įrankis, kuriuo ji gali suvienyti valstybę - toki teigini patvirtina Europos standartiniu kalbu formavimasis ir ju ittvirtinimas" (Smetonienė 2014). Taigi požiūris į kalbą ir įsitikinimai dažniausiai būna susiję ne su kalba ar kalbos realiaja vartosena, o su politiniais sprendimais (Buivydiené 2013; 2014).

Šiame straipsnyje, remdamiesi Europos bendriniu kalbu raidos teorijomis, siekiame aptarti vèlyvo lietuviu bendrinės kalbos susiformavimo priežastis. Siekiant šio tikslo keliami šie uždaviniai: 1. Aptarti bendrinių kalbu raidos teorijas atsižvelgiant $i$ bendrinès kalbos sampratą. 2. Remiantis bendrinių kalbu raidos teorijomis, išskirti lietuvių bendrinès kalbos raidos etapus. 3. Nustatyti socialinių ir kultūriniu aplinkybiu ịtaką lietuvių bendrinès kalbos raidai. Darbe remiamasi mokslinès literatūros analizès, kokybinès turinio analizès, kalbos istorijos faktu lyginimo ir gretinimo metodais.

\section{BENDRINIŲ KALBŲ RAIDOS TEORIJŲ ASPEKTAI}

Nors šiuolaikiniu Europoje plačiausiai vartojamu bendriniu kalbu susiformavimo aplinkybès skirtingos (Haugen
1972; Subačius 2004; Pupkis 2005), daugumai būdinga kodifikacija - tam tikros gramatikose, žodynuose, vadovèliuose, 
Lentelè. Haugeno schema (Haugen 1972: 252)

\begin{tabular}{|l|l|l|}
\hline & Forma (angl. Form) & Funkcija (angl. Function) \\
\hline Visuomenė (angl. Society) & Pasirinkimas (angl. Selection) & Prièmimas (angl. Acceptance) \\
\hline Kalba (angl. Language) & Kodifikavimas (angl. Codification) & Tobulinimas (angl. Elaboration) \\
\hline
\end{tabular}

praktiniuose bendrinès kalbos vartojimo patarimuose ir žinynuose aprašytos bendrinès kalbos vartojimo taisyklès (Buivydienė 2013; Smetonienè 2014; Buivydienè 2014; Pupkis 2005). Tai labiausiai skiria bendrines kalbas nuo ivvairių kitų kalbos atmainų ir atšakų.

Bendrinių kalbų teorijoms svarbią įtaką padare $1972 \mathrm{~m}$. sociolingvisto Einaro Haugeno suformuluoti bendrinès kalbos raidos etapai, kuriuos pats autorius vadino aspektais: 1) atranka (pasirenkamas bendrinès kalbos pagrindas); 2) kodifikacija (raštu fiksuojamos bendrinès kalbos normos); 3) funkciju plètra (bendrinè kalba apima įvairias viešojo gyvenimo sritis pagal kalbinès bendruomenės poreikius); 4) pripažinimas (sunormintoji kalbos atmaina kalbinès bendruomenès pripažistama kaip prestižinè ir visuotinai palaikoma) (Haugen 1972: 252; Subačius 2004: 104-107; Miliūnaitè 2010: 234; Buivydienè 2013: 11). Haugenas savo schemą pristate išskirdamas, jo nuomone, du svarbiausius standartizavimo procesus socialinius ir lingvistinius, todèl schemoje etapai buvo pateikti matricos forma, o ne pakopomis (žr. lentelę).

Pasak Haugeno, pirmasis vykstantis socialinis procesas - varianto pasirinkimas iš esamu tarmių. Dažniausiai pasirenkama dominuojančios socialinès grupès tarmè. Kai variantas pasirinktas, jis turi būti priimtas kitų kalbinès bendruomenès narių. Haugenas skiria funkcijų plètrą (tobulinimą) ir kodifikaciją. Kai tarmè turi tenkinti išsivysčiusios visuomenès poreikius, reikia susikurti papildomų kalbinių įrankių: rašytinę formą, sintaksinę struktūrą, tinkančią vartoti rašytiniuose dokumentuose, žodyną, tenkinantį visus viešojo gyvenimo poreikius ir kt. Buvusi tarmè turi funkcionuoti jau kaip standartas. Tam reikalinga kodifikacija - gramatikos aprašas, kur būtų aprašyta, kurios gramatikos, sintaksès ir leksikos formos yra taisyklingos (Haugen 1972).

Haugeno aspektus Dickas Leithas (Leith 1983) ir Jamesas bei Lesley Milroy'jai pavadino etapais ir kai kuriuos etapus sukeitè vietomis. Leithas ir Milroy'jai kodifikavimo etapą nurodo kaip paskutinijij, vèliausiajij, o normos prièmimas vyksta anksčiau - antruoju etapu. Be to, Milroy'jai šiuos etapus vadina ne bendrinès kalbos raidos etapais, o standartiniu kalbu standartinio i̇diegimo etapais - taigi kalbama apie idiegimo laiką ir jo etapus: „Mes manome, kad šiuos etapus reikètu vadinti normos įdiegimo etapais, o ne norminimo aspektais" (Milroy J., Milroy L. 1999: 23).

Mažiausiai nuo Haugeno teorijos nutolo R. Anthony'is Lodge'as (1993), kuris tik paskutinius du Haugeno aspektus sukeitè vietomis ir pavadino ne aspektais, o fazèmis ir procesais. Milroy'jai (1999: 23) dar pabrèžè priežiūros etapa, kuris prasideda iš karto, kai tik pasirinktasis variantas yra priimamas, ir tęsiasi visada, nesibaigia niekada. Funkcijų to- 
bulinimo etapu bendrinè kalba tampa prestižine, plačiai vartojama visose srityse (oficialiuosiuose dokumentuose, švietimo sistemoje ir kt.). Žinoma, kodifikacija paskatina ir preskriptyvizma, nes tuo etapu kalbos vartotojai labiau pasitiki kodifikacijos darbais, o ne natūraliąja vartosena (Milroy J., Milroy L. 1999: 23).

Pažymètina, kad lietuvių kalbininkai (Pupkis 2005; Miliūnaite 2018) išskiria ir dar vieną etapą: kodifikacijos teorijos kūrimas ir tobulinimas, kalbos funkciju plèt- ra, didesnė ar mažesnè kalbos normu destabilizacija. Lietuvoje šis etapas nurodomas maždaug nuo $2001 \mathrm{~m}$. iki dabar (Miliūnaitè 2018: 66). Rita Miliūnaitè normų destabilizacijos etapą aiškina kaip pastebimą bendrinès kalbos vartosenos raiškos priemoniu variantiškumo didejjima, nemotyvuotų normų pažeidimų gauséjimą. Be to, bendrinès kalbos normas veikia atsiradusios naujos standartinès kalbos vartojimo sritys, ypač susijusios su elektronine terpe (Miliūnaitè 2018: 67).

\section{LIETUVIŲ BENDRINĖS KALBOS RAIDA}

Remiantis šiomis bendrinių (standartinių) kalbu raidos teorijomis, lietuviu bendrinès kalbos i̇diegimo procesas vyko XIX a. pabaigoje-XX a. pradžioje. Palyginti su kitų kalbų standarto įsitvirtinimu - tai vèlyvas bendrinès kalbos idiegimo atvejis. Haugenas (1972), apžvelgdamas Vakaru Europos bendrinių kalbu raidą, atkreipia dèmesí, kad iki Renesanso rūpintis kalba buvo palikta "gramatikams ir retorikams", kurie skelbė apie kalbos groži ir poveikị klausytojams, tačiau su valstybès valdymu ir vienu kalbos standartu tai neturejjo nieko bendra. Visai kitaip į kodifikavimą ir jo prasmę imta žiūrèti jau nuo XV a. (Haugen 1972; Smetonienè 2014): Ispanijos, Italijos, Prancūzijos atvejai rodo bendrinių kalbų sąmoningą parinkimą, kai bendrinès kalbos varianto paskelbimas (Prancūzijoje dvaro kalbos, Italijoje ir Ispanijoje - vieno iš dialektų) tampa valstybès politikos dalimi ir atlieka valstybès valdymo ir vienijimo vaidmeni (Haugen 1972; Smetonienè 2014). Visai kitoks bendriniu kalbų susiformavimo kelias išryškejjo tose valstybėse, kuriose kalbos standartizavimo idejos kilo „iš apačios" - nulemtos tautos išsilaisvimo ir tautiškumo išsaugojimo ideju (pavyzdžiui, slovakų, čekų ir vengrų kalbų santykis) (Smetonienè 2014).

Nagrinejjant lietuvių bendrinès kalbos susiformavimo ištakas - tik XIX a. pabaigoje-XX a. pradžioje, - galima pastebèti tam tikru istorinių, kultūrinių ir politiniu aplinkybių sąveikos įtaką. Pasak Subačiaus (1998: 19), lietuviu kalba priklausytu „vèlyvojo tarmès pasirinkimo ir norminimo jau Romantizmo laikotarpiu bendriniu kalbu grupei“. Tokia, palyginti vèlyva, bendrinès lietuvių kalbos raidą nulemė lietuviškosios spaudos draudimas ir kiti politiniai įvykiai, tačiau reikia atkreipti dèmesí, kad vèlyvas pasirinkimas būdingas ne tik lietuvių kalbai. Vèlyvo bendrinių kalbu susiformavimo priežastys gali būti įvairios, aiškinamos tuo, kad dèl politiniu aplinkybių lètesnį tokių šaliu bendrinių kalbų kūrimąsi lèmé tai, kad, pasak Subačiaus, ilgą laiką „itakingieji visuomenès sluoksniai 
labiau buvo linkę vartoti kitas gimtąsias (angl. vernacular) kalbas" (Subačius 1998: 19). $X V$ a., kai ispanai jau buvo pasirinkę savo kalbos standarta, Lietuvoje lietuviškai privačiame gyvenime kalbejjo kaimo žmonès, miestiečiai ir kai kurie smulkieji bajorai, o valstybès raštuose buvo ịsitvirtinusi rytiniu slavu kalba (nes tuo metu lietuvių rašytinės kalbos nebuvo), su kitomis šalimis susirašinejama lotyniškai. Maždaug nuo XVI a. pradžios viešajame gyvenime pasirodè lenkų kalba (Smetonienè 2014). XIX a. viešojoje erdveje buvo vartojama rusų kalba. Taigi lietuvių kalba iki XIX a. pabaigos$X X$ a. pradžios nebuvo vartojama viešojo gyvenimo reikèms, pavieniai spausdintiniai šaltiniai, parašyti lietuviškai, buvo rašomi skirtingais rašytinès lietuvių kalbos variantais.

Irenos Smetonienès manymu, XIX a. pradžioje Lietuvą neabejotinai buvo pasiekę Didžiosios prancūzų revoliucijos teiginiai apie naują tautos sąvoka, kurioje kalba (ypač standartinè) vaidina svarbų vaidmeni (Smetonienė 2014). Be to, XIX a. Europoje vyravusio Romantizmo nulemtas demesys istorijai, tuo metu atsiradusios ir išpopuliarejusios lyginamosios kalbotyros mokslininkų dėmesys lietuvių kalbai, kaip išlaikiusiai daugiausiai indoeuropiečiu prokalbės bruožų, paskatino ir tautiškumo bei dèmesio kalbai idejjas ir Lietuvoje. Vèliau, XX a. pirmaisiais dešimtmečiais, kai Vakarų Europoje dominavo Ferdinando de Saussure'o ir jo mokiniu struktūrinès lingvistikos idejjos, kad kalbą reikia nagrinèti kaip sistemą (Pupkis 2005: 49), Lietuvoje 1901 m. Petro Kriaušaičio gramatika itvirtino pasirinktajji rašytinį normos va- riantą - atliko pagrindini normos kodifikavimo darbą. Po spaudos draudimo panaikinimo buvo sudarytos sąlygos toliau plètotis bendrinès lietuviu kalbos funkcijoms: buvo kuriamos pirmosios lietuviškos lietuviu kalbos programos, rašomi mokykliniai vadovèliai, jų recenzijos, diskutuojama spaudoje, sukurtas rašomosios kalbos terminas (plačiau Buivydienè 2013; 2014).

$X X$ a. pradžioje nusistovejo pasirinktasis bendrinès kalbos variantas - vakarų aukštaičiu kauniškių tarmès pagrindu. Taigi XIX a. pabaigoje-XX a. pradžioje lietuviu bendrine kalba teoriškai jau galejjo tenkinti visos lietuviu tautos bendravimo ir kultūrinio gyvenimo poreikius: pasirinktasis variantas plačiai paplito visoje Lietuvoje socialine ir geografine prasme. Bendrinès kalbos variantas buvo priimtas, prasidejo kodifikacijos ir funkcijų plètros etapai, kurie lietuvių bendrinès kalbos atveju vyko beveik kartu (tokio atvejo galimybę patvirtina ir Milroy'jai, teigdami, kad šie hipotetiniai etapai nebūtinai turi vykti vienas po kito (Milroy J., Milroy L. 1999: 23).

Lietuvių bendrinès kalbos pagrindinę normų kodifikacijos funkciją $1901 \mathrm{~m}$. atliko Petro Kriaušaičio Lietuviškos kalbos gramatika. Toliau reikejjo ịtvirtinti ir sunorminti bendrinès kalbos vartoseną viešojoje erdvejje, o vienas iš svarbiu būdu i itvirtinti normą - ją diegti nuo pat pirmujų mokymo metų mokykloje (Buivydienė 2013). Nuo XX a. pradžios prasidejjo bendrinès kalbos norminimo funkcijų tobulinimo - darbas, kuris ypač sustiprëjo nuo 1918 m., Lietuvai tapus nepriklausoma valstybe (bendrinè kalba èmé funkcionuoti ir valstybès, ir admi- 
nistraciniame gyvenime, spaudoje, mokyklose), - ir galiausiai iž̌engè i ketvirtajji Haugeno aprašytą bendrinès kalbos formavimosi etapa, kai sunormintoji kalbos atmaina visuotinai pripažistama, visuomenè jai pritaria. Lietuvių bendrinès kalbos istorijos atveju tinka Milroy'ju prie Haugeno schemos pridètas dar vienas etapas - priežiūros, kuris prasideda labai anksti, todèl apima funkciju tobulinimo ir kodifikavimo etapus, ir tęsiasi visą laiką (Milroy, Milroy 1991: 22). Šią minti papildo Lodge'as, kuris Haugeno teoriją pritaikè analizuodamas prancūzų kalbos istorija, teigdamas, kad kalbos normu standartizavimas yra nesibaigiantis procesas, nes norint išlaikyti įtvirtintąji kalbos varianta, vyksta nuolatine kova (Lodge 1993: 27). Lodge'as (1993: 27) taip pat kalba apie priežiūros etapą. O Milroy'jų nuomone, visiškas galutinis kalbos sunorminimas yra neįmanomas visiškai sunorminta gali būti tik mirusi kalba (Milroy, Milroy 1999: 19) - ši teigini patvirtina dabartinių kalbų vartosenos tyrimai (Miliūnaitè 2018).

Lietuvių bendrinès kalbos raidos etapai greitai keitè vienas kita, todèl tiksliai nustatyti ju ribas yra labai sudètinga. Forma buvo pasirinkta XIX a. pabaigoje, tai rodo laikraščių Aušra ir Varpas kūrèju ir bendradarbiu pastangos (Zinkevičius 2000: 102), o pasirinktąji variantą galutinai įtvirtino 1901 m. Kriaušaičio gramatika, kuria iki pat 1922 m. rèmėsi mokyklinių gramatikų ir vadovèlių autoriai. Kriaušaičio gramatika ir jos pagrindu parašyti mokykliniai vadovėliai tuo laiku atliko ir normos kodifikavimo, ir sklaidos (funkcijų tobulinimo) funkcijas, nes augino jaunają kartą pratindami nuo mokyklos laikų prie bendrinės kalbos, analizuodami tarmių ir bendrinès kalbos skirtumus (Buivydienè 2013; 2014). Funkcijų tobulinimo ir bendruomenès prièmimo etapai iš dalies sutapo su Nepriklausomybès paskelbimu, nes tuo metu labai aktyviai buvo dirbamas ir lietuvių bendrinès kalbos norminimo darbas, ir bendrinè kalba sparčiai paplito viešojoje vartosenoje.

Pasirinkus bendrinès kalbos forma, vis dar reikëjo tvarkyti visas kalbos sritis: $X X$ a. pradžioje reikèjo suvienodinti įvairuojančią rašyba, gryninti, norminti ir turtinti leksiką ir sintaksę, kurti naujus terminus, nustatyti pastovesnes kalbos normas, suformuluoti kalbos norminimo kriterijus. Tuo metu buvo suvokta, kad bendrinès kalbos normų sisteminimas, nustatymas ir diegimas i vartoseną - sudètingas procesas. Taigi XX a. pradžioje buvo pradètas nuoseklus praktinis dabartinių normų nustatymo ir ittvirtinimo darbas, kuri dar XIX a. pabaigoje pradèjo ir toliau tęsè Jonas Jablonskis, Kazimieras Būga, vèliau Juozas Balčikonis, Antanas Salys, Pranas Skardžius ir kiti kalbininkai.

Sukūrus nepriklausomą Lietuvos valstybę, reikejjo plèsti bendrinès (rašomosios ir šnekamosios) kalbos vartojimo sritis bei funkcijas ir vis dar rūpintis, pasak Zinkevičiaus, kalbos kodifikacija ir stabilizacija (Zinkevičius 199: 279).

Nuo XX a. ketvirtojo dešimtmečio, kai norminamoji veikla pasidarè organizuotesnè, kai ėmėsi veiklos Lietuvių kalbos draugija, imta aktyviau svarstyti ir teorinius bendrinès kalbos norminimo klausimus (Miliūnaitė 2003: 13). Kodifikuotų ir stabilių bendrinès kalbos normų ypač reikëjo Lietuvos mokykloms, kurių vis gausejo ir kuriose imta mokyti visu 
dalyku gimtaja kalba. Be nusistovejjusių rašybos, tarties, gramatikos normu nebuvo i̇manomas sèkmingesnis ne tik švietimo, bet ir mokslo, administracijos ir apskritai kultūros darbas (plačiau žr. Zinkevičius 1992: 279).

Reikia pabrèžti, kad funkciju tobulinimo etapu bendrinè kalba tampa prestižine, plačiai vartojama visose srityse (oficialiuosiuose dokumentuose, švietimo sistemoje ir kt.) $)^{1}$ XX a. daugelis valstybiu pradeda kalbą reglamentuoti tiesiogiai: konstitucijos ittvirtina valstybines kalbas, kai kur priimami atskiri kalbos istatymai (Smetonienė 2014). Haugeno išskirti trečiasis ir ketvirtasis etapai pavedami koordinuoti arba komisijoms, arba kalbos taryboms. Atsiranda naujas reiškinys - kalbos arba kalbų politika.

Apibendrinant galima teigti, kad lietuviu bendrinès kalbos raidos istorijoje galima įžvelgti labai ryškią politinių ir socialinių reiškinių įtaką - ypač sugretinus lietuvių ir Vakarų Europos kalbotyros krypčių raidą. Pirmaisiais XX a. dešimtmečiais lietuvių kalbininkams didžiausią itaką dare de Saussure'o ir jo mokiniu struktūrinès kalbotyros idejjos ir struktūrinis požiūris i kalbos reiškinius, tai rodo pirmieji Jablonskio darbai, o nepriklausomos Lietuvos laikotarpiu lietuviu kalbininkai rémėsi Vakaru Europos kalbininku darbais, tai rodo Gimtosios kalbos mokyklos ideologinès sąsajos su Prahos lingvistine mokykla ir bendrinès kalbos idejos. Funkcijų tobulinimo etapas tęsiasi iki šių dienu, tačiau nuo $2001 \mathrm{~m}$. lietuvių bendrinès kalbos viešojoje vartosenoje vis ryškiau pastebima normu destabilizacija ir variantiškumo gausejimas, nepaisant bendrinès kalbos reguliavimo valstybinių institucijų ir politiniu lygmeniu.

\section{IŠVADOS}

1. Bet kuri kalba, kol tampa bendrine, išgyvena mažiausiai kelis etapus. Jų sẻkmė ir trukmè priklauso nuo valstybès požiūrio ir tikslo, nuo valstybės apsisprendimo kalbą itraukti i bendrąją savo politiką. Bendrinès kalbos sąvoka yra istorinè, per laiką kintanti kategorija, bet būtent ji labiausiai skiria bendrines kalbas nuo įvairių kalbos atmainų ir atšakų.

2. Remiantis bendrinių kalbu raidos teorijomis galima teigti, kad lietuviu bendrinès kalbos i̇diegimo procesas vyko XIX a. pabaigoje-XX a. pradžioje - tai vèlyvo bendrinès kalbos pasirinkimo ir įdiegimo atvejis, nagrinè- jant Vakaru Europos kontekste, nulemtas Lietuvai poveiki dariusių sociokultūrinių ir politinių aplinkybių.

3. Kiti lietuvių bendrinès kalbos raidos etapai greitai keitè vienas kita, kai kurie vyko greta. Naujausią bendrinès lietuvių kalbos raidos etapą galima ivvardyti kaip kalbos funkciju plètros ir normų destabilizacijos tarpsnį: dèl natūralių socialinių aplinkybių lietuviu kalba patiria kitu kalbu ir technologiju itaka, kuri lemia didesnius ar mažesnius kalbos normų pažeidimus viešojoje vartosenoje ir didejanti raiškos priemonių variantiškumą. 


\section{Literatūra}

Buivydienė Vaida. 2013. XX amžiaus pirmosios pusés pradžios mokyklu gimtosios kalbos vadovèliu turinio ir kalbos norminimo bruožai. Daktaro disertacija, Vilnius.

Buivydienė Vaida. 2014. Lietuvių bendrinės kalbos raida: ekolingvistinis požiūris. Santalka 22(1): 1-11.

Haugen Einar. 1972. The Ecology of Language. Essays by Einar Haugen. Selected by Anwar S. Dil. California: Stanford University Press.

Leith Dick. 1983. A Social History of English. London and New York: Routledge.

Lodge Raymond Anthony. 1993. French: from Dialect to Standard. London and New York: Routledge.

Miliūnaitė Rita. 2003: Lietuviu kalbos gramatikos norminimo pagrindai. Vilnius: Lietuvių kalbos institutas.

Miliūnaitė Rita. 2006. Kodifikacijos ir vartosenos santykių modelis. Kalbos kultūra 79, 9-28.

\section{Nuorodos}

${ }^{1}$ Tačiau kodifikacija, kaip minèta, paskatina ir preskriptyvizma, nes tuo etapu kalbos vartotojai labiau pasitiki kodifikacijos darbais, o ne natūraliąja vartosena - kad ir kiek klaidų būtu
Miliūnaite Rita. 2018. Kalbos normos ir ju savireguliacija interneto bendruomenejje. Vilnius: Lietuviu kalbos institutas.

Milroy James, Milroy Lesley. 1999. The Authority of Language. Investigating Standard English. London and New York: Routledge.

Pupkis Aldonas. 2005. Kalbos kultūros studijos. Vilnius: Gimtasis žodis.

Smetonienė Irena. 2014. Kalbos vieta valstybiu politikoje: standartiniu kalbų susikūrimas. Parlamento studijos. Mokslo darbai 16.

Subačius Giedrius. 2004. Standartinių (bendrinių) kalbu istorijos. Metmenys 84: 97-115.

Zinkevičius Zigmas. 1992. Lietuvių kalbos istorija 5: Bendrines kalbos iškilimas. Vilnius: Mokslo ir enciklopedijų leidykla.

Zinkevičius Zigmas. 2000. Elementorių kalba. Lietuviški elementoriai. Kaunas: Šviesa, 95-98.

knygose, ju (knygų) lingvistinė kompetencija atrodo patikimesnè, negu pačių kalbos vartotoju , kurie vartoja kalbą kiekvieną dieną (Milroy J., Milroy L. 1999: 23). 